matical classics. The most recent batch illustrates the wide variety which has been selected. Salmon's Higher Plane Curves (4.95 dollars) and Bell's revision of Frost's Curve Tracing (3.50 dollars) are museum pieces, no longer recommended reading but held in warm affection by all who know them. Projective Geometry (4.95 dollars) is a translation of the second part of the 1935 book by Schreier and Sperner, the first part having already been issued in translation by the Chelsea Co., under the title of Modern Algebra and Matrix Theory; this completes the version of a work which, if now a little out of date, is still recommended by the experts as a suitable introductory university text on algebra and algebraic geometry. Then an omnibus volume (6 dollars) contains two monographs by Weyl, Das Kontinuum and Mathematische Analyse des Raumproblems, Landau's tract (1916, second edition 1929) on function theory, which inspired so many undergraduates in the 'twenties, and the famous Riemenn dissertation, on the foundations of geometry, with Weyl's notes. The books are well produced and stoutly bound, and many libraries, private and public, may be glad of the opportunity to fill gaps reasonably cheaply.

\section{The International Society for Stereology}

THE International Society for Stereology was established during May 1961. Stereology is the science of three-dimensional interpretation of flat images, such as sections and projections, that is, the extrapolation from two- to three-dimensional space. The methods range from the evaluation of shadows through serial sections to statistico-geometrical analysis. Stereology finds applications in microscopical anatomy, electron microscopy, geology, metallurgy, aerial mapping, astronomy and cosmology. The Society is holding its first congress at Key Biscayne, Florida, during April 24-26, 1962. Further information concerning the Society and the congress can be obtained from Dr. Hans Elies, Department of Anatomy, Chicago Medical School, 710 South Wolcott Avenue, Chicago 12, Illinois.

\section{Postgraduate Courses at the Imperial College of Science and Technology}

INFORMATION contained in a booklet (Shorter Postgraduate Courses) issued by the Imperial Colloge of Science and Technology relates to shorter postgraduate courses to be held at the College during the autumn term of the session 1961-62, and advance information on those to be held during the spring and summer terms. The courses included comprise not only those specially arranged but also a selection of lecture courses forming part of the normal departmental syllabuses, where these are likely to be of interest to students as separate courses and where it is possible to accept part-time students. The booklet is divided into two sections covering part-time courses and short full-time courses. Further information on all these courses can be obtained from the Registrar, Imperial College of Science and Technology, Prince Consort Road, London, S.W.7. Details of full-time postgraduate courses extending over one year are given in a separate booklet, Postgraduate Courses, which is obtainable from the Registrar, price $2 s$.

\section{B.B.C. Research Scholarships}

$\mathrm{E}_{\mathrm{ACH}}$ year the B.B.C. awards research scholarships (valued at $£ 500$ per annum) to university graduates in electrical engineering or physics, to enable them to work at any university in the United Kingdom for a higher degree in those fields of telecommunications or physics which have an application to sound or television broadcasting. This year, three scholarships have been awarded: to $\mathrm{Mr}$. J. Elliott (1 year), of the Imperial College of Science and Technology, London, who has been working under Prof. C. Cherry and Mr. J. Roberts; to Mr. K. L. Hughes (2 years), of the University of Birmingham, for work under Prof. D. G. Tucker and Prof. J. T. Allanson at Birmingham; to Mr. B. J. Tilley (2 years), of the University College of Swansea, who will work at Swansea under Prof. W. Fishwick and Mr. J. MacCormack.

\section{University News:}

Southampton

THE title of reader in botany has been conferred on Dr. J. M. Lambert.

\section{Loughborough College of Technology}

DR. G. F. REYNolDs has been appointed reader in analytical chemistry at Loughborough. Previously, Dr. Reynolds was a principal scientific officer in the Chemical Inspectorate at the War Office.

\section{Announcements}

Dr. Sigvard EkLund, of Sweden, has been appointed director-general of the International Atomic Energy Agency, in succession to Mr. Sterling Cole, whose term of office expires on November 30.

SrR WILLIS JACKson has been elected president of the British Association for Commercial and Industrial Education.

STAFFORD BEER, founder of the Department of Operational Research and Cybernetics, United Ste日l, has now become managing director of SIGMA (Science in General Management), Ltd. SIGMA was recently set up to offer professional services in operational research to industry and Government. Roger Eddison is now director of operations of SIGMA. Previously Mr. Eddison was manager of the Plans and Mothods Department in NAAFI.

Mr. C. T. Melinga, a deputy chairman of the Electricity Council, has been appointed a member of the Advisory Council on Research and Development of the Ministry of Power, in succession to Sir Josiah Eccles.

MR. L. H. WELCH, recently chief electrical engineer to the London Electricity Board, has been appointed as industrial relations consultant to the British Electrical and Allied Industries Research Association.

Sir CyrIL HINSHELwood, past president of the Royal Society, will deliver the 1961 Eddington Memorial Lecture in Cambridge at the Arts School Lecture Theatre, Bene't Street, on November 10, at 5 p.m. The title of the lecture is "The Vision of Nature".

The Natural Rubber Producers' Research Association is holding a symposium under the general title, "Fundamental and Practical Approaches to Ageing Protection", at its laboratories at Welwyn Garden City during November 2-3. Attendance will be by invitation only. Further information can be obtained from the Natural Rubber Bureau, 19 Buckingham Street, Adelphi, London, W.C.2.

THE Association of Universities of the British Commonwealth has issued invitations to its member universities to appoint delegates to the ninth quinquennial Congress of Universities of the Commonwealth, which will be held at the University of London during July 15-19, 1963, and which will mark the jubilee of the founding of the Association. 